\title{
Regulation A+ Sebagai Alternatif Penghimpun Dana Untuk UMKM Dan Start-Up
}

\author{
Dinda Silviana Putri \\ Fakultas Hukum, Universitas Surabaya, silvianadinda@gmail.com
}

\begin{abstract}
Capital is a problem that is often faced by start-up companies and Micro, Small and Medium Enterprises (MSMEs). On the other hand, these activities are often the choice of Indonesia's lower and middle class as an effort to improve their economy. For this reason, the Government through the Financial Services Authority (OJK) provides steps to raise capital through a crowdfunding method using information technology (equity crowdfunding / ECF). ECF activities are a solution for start-ups and MSMEs to raise capital in ways that are almost similar to Initial Public Offering (IPO) activities by involving publishers, organizers, and investors. Unfortunately, even though it has been going on since 2018, business activities using the ECF as a real effort to provide additional capital have not been maximally implemented. This is because there are several records that can hinder the optimization of the ECF itself, such as the Investors criteria, shares Flexibility, and maximum securities ownership.

This research is normative legal research using a conceptual approach, a statutory approach, and a comparative approach and the development of ECF regulations in Indonesia and reformation on investor limitation law in the ECF in Indonesia as research problems.

The results of this study indicate that the application and regulation of the ECF in Indonesia still have various deficiencies. Therefore, a solution is needed by adopting several provisions in Regulation A + in America as an effort to overcome these deficiencies.
\end{abstract}

Keywords: MSEMEs; Start up; Equity Crowdfunding; Regulation A+

\begin{abstract}
Abstrak
Modal merupakan permasalahan yang sering dihadapi oleh perusahaan rintisan (start-up) dan Usaha Mikro, Kecil, dan Menengah (UMKM), di lain sisi, kegiatan tersebut seringkali menjadi pilihan masyarakat kelas menengah bawah Indonesia sebagai upaya peningkatan ekonomi mereka. Untuk itulah, Pemerintah melalui Otoritas Jasa Keuangan (OJK) memberikan langkah pengumpulan modal melalui metode urun dana dengan memanfaatkan teknologi informasi (equity crowdfunding/ECF). Kegiatan ECF menjadi solusi bagi start up dan UMKM untuk memperoleh modal dengan cara-cara yang hampir mirip dengan kegiatan Initial Public Offering (IPO) dengan melibatkan penerbit, penyelenggara, dan pemodal. Sayangnya, meskipun sudah berlangsung sejak tahun 2018, kegiatan usaha dengan memanfaatkan ECF sebagai upaya nyata untuk memberi tambahan modal belum berlangsung secara maksimal. Hal ini dikarenakan terdapat beberapa catatan yang dapat menghambat optimalisasi ECF itu sendiri, seperti adanya kriteria pemodal, penjualan saham kembali, dan maksimal kepemilikan efek.

Penelitian ini merupakan penelitian hukum normatif dengan menggunakan pendekatan konsep, pendekatan perundang-undangan, dan pendekatan perbandingan dan perkembangan regulasi ECF di Indonesia dan reformasi aturan hukum batasan investor dalam ECF di Indonesia sebagai rumusan Masalah.
\end{abstract}

Jurnal

YUSTIKA

Media Hukum dan Keadilan Fakultas Hukum Universitas Surabaya Vol. 24 No. 01, Juli 202 E-ISSN: 1410-7724 
Hasil penelitian ini menunjukkan bahwa penerapan dan regulasi ECF di Indonesia masih memiliki berbagai kekurangan. Karenanya, diperlukan solusi dengan mengadopsi beberapa ketentuan dalam Regulation A+ di Amerika sebagai upaya mengatasi kekurangan tersebut.

Kata Kunci: UMKM, Start up; Urun Dana Berbasis Teknologi Informasi; Regulation A+.

\section{Pendahuluan}

Suatu negara dapat secara nyata dikatakan sebagai negara maju, jika negara tersebut telah mampu mensejahterakanmenjamin kesejahteraan kepada rakyatnya dari berbagai bidang, dimana salah satu bidang tersebut adalah segi perekonomian negara. Dalam kaitannya dengan hal tersebut, Friedmann menyampaikan bahwa negara memiliki empat fungsi utama, yakni sebagai penyedia layanan sosial, sebagai pelaku usaha, sebagai regulator, dan sebagai wasit yang bertanggung jawab atas proses peradilan. (Nigel Savage, 1993) Fungsi utama negara sebagai regulator, jika dilihat dari tujuan memajukan pergerakan ekonomi, maka negara dituntut untuk membentuk suatu aturan perundang-undangan yang mendukung setiap kegiatan-kegiatan bisnis guna memaksimalkan perputaran roda perekonomian negara.

Refleksi dari fungsi tersebut, maka negara harus berperan dalam menfasilitasi kegiatankegiatan yang dilakukan oleh masyarakat. Fasilitas yang dimaksudkan adalah melalui sebuah kebijakan-kebijakan. Saat ini sektor yang perlu mendapatkan perhatian dan perlu untuk terus dilakukan pengembangan adalah di bidang penanaman modal. Sudah barang tentu menjadi pengetahuan umum meskipun Indonesia telah dinyatakan sebagai negara maju, namun pada kenyataannya masih jauh dari kata maju itu sendiri. Indonesia masih memerlukan bantuan dari negara-negara lain untuk mengembangkan perekonomiannya.

Indonesia sebagai host state harus mampu bersaing dengan negara-negara lain agar menarik minat investor sebagai upaya membantu pergerakan ekonomi. Kebijakan yang mendukung proses penanaman modal, tentu menjadi salah satu faktor yang akan mempengaruhi minat dari investor. Kegiatan penanaman modal sendiri dibagi menjadi dua, yakni penanaman modal langsung dan penanaman modal tidak langsung. Pembeda dua kategori tersebut terdapat pada peranan dari pihak investor, dimana dalam penanaman modal langsung, investor berperan secara langsung dalam mengelola perusahaan atau kegiatan usaha yang bersangkutan, sehingga pihak investor juga menanggung secara langsung resiko yang mungkin terjadi. Sedangkan dalam penanaman modal tidak langsung, investor tidak berperan secara langsung dalam mengelola operasional perusahaan.

Salah satu lahan yang berkembang dalam penanaman modal tidak langsung saat ini adalah perusahaan-perusahaan startup, perkembangan startup ramai dibicarakan di tengah masyarakat. Kondisinya saat ini banyak pelaku bisnis e-commerce pemula (startup) baik perdagangan online maupun startup digital dengan ide-ide segar dan inovatif yang kurang memiliki akses atau pendanaan untuk mengembangkan bisnisnya. (Lukito, 2017) Apalagi bila menengok startup-startup yang telah sukses melenggangkan usahanya di Indonesia seperti GoJek. Go-Jek saat ini telah masuk kategori decacorn, yakni sebuah startup yang memiliki valuasi lebih dari 10 milliar. Di bawah decacorn masih ada perusahaan dengan kategori unicorn di Indonesia, seperti Tokopedia, Traveloka, Bukalapak dan OVO. Meski demikian dalam mengembangkan perusahaan startup tersebut bukanlah perkara mudah. Terutama saat membahas perihal modal untuk pendanaan pendirian hingga pengelolaannya.
Jurnal Yustika Vol. 24 No. 01, Juli 2021

Halaman | 38 Regulation At Sebagai Alternatif Penghimpun Dana Untuk UMKM DAN Start-Up

Dinda Silviana Putri 
Jurnal Yustika

Vol. 24 No. 01, Juli 2021

Halaman I 39

Regulation A+

Sebagai Alternatif

Penghimpun Dana Untuk UMKM DAN Start-Up

Dinda Silviana Putri
Selain Startup, terdapat Usaha Mikro, Kecil dan Menengah (UMKM) sebagai sektor yang harus diberi perhatian khusus pula agar mampu berkembang layaknya sektor-sektor lainnya. Mengingat UMKM sebagai kegiatan usaha kecil menengah, tidak jauh berbeda dengan startup, keduanya memiliki hambatan dalam hal permodalan. Permasalahan tersebut meliputi jumlah maupun sumber modal, kurangnya kemampuan manajerial dan minimnya keterampilan dalam operasional menjadi masalah dasar yang sering dihadapi oleh UMKM. (Suci, 2017)

Kegiatan untuk mengumpulkan dana bagi perusahaan sendiri setidaknya ada tiga cara yakni dari modal pemegang saham, pinjaman dari perbankan dan ketiga adalah dengan menawarkan ke pasar modal. Cara ketiga merupakan cara yang harus dilakukan jika cara pertama dan kedua tidak dapat ditempuh. Permasalahan lain yang harus dihadapi adalah ketika perusahaan akan menawarkan efeknya di bursa efek, mereka harus terlebih dahulu melalui mekanisme penawaran umum atau Initial Public Offering (IPO). Mas Rahmah dalam bukunya menjelaskan bahwa motivasi utama sebuah perusahaan melakukan penawaran umum adalah untuk memperoleh dana yang diperuntukkan sebagai biaya modal atau biaya proyek investasi. (Dr. Mas Rahmah, 2019) Terdapat syarat-syarat yang harus dipenuhi oleh sebuah perusahaan sebelum menjadi perusahaan terbuka. Syarat-syarat ini tidak jarang justru dapat memberatkan, terutama bagi perusahaan yang baru mulai berkembang dengan skala kecil.

Pemerintah Indonesia, kiranya saat ini telah menyadari akan pentingnya dari UMKM maupun startup. Hal tersebut terlihat dari, salah satu kebijakan yang dikeluarkan oleh Otoritas Jasa Keuangan (OJK), OJK melalui Peraturan Otoritas Jasa Keuangan Nomor 37/POJK.04/2018 tentang Layanan Urun Dana Melalui Penawaran Saham Berbasis Teknologi Informasi (POJK 37/POJK.04/2018) memberikan jalan bagi emiten-emiten yang memiliki aset kecil dan menengah untuk memperoleh dana seperti di dalam pasar modal. Aturan tersebut mengatur mengenai pendaftaran saham untuk emiten dengan skala aset kecil dan menengah. Kegiatan pengumpulan dana yang diatur dalam POJK 37/POJK.04/2018 merupakan kegiatan urun dana atau bisa disebut sebagai Equity Crowd Ffunding (ECF). Dalam kegiatan ECF terdapat tiga pihak yang terlibat di dalamnya, yakni penerbit (emiten), penyelenggara, dan pemodal/investor. POJK 37/POJK.04/2018 kemudian pada tahun 2020 dicabut dan dinyatakan tidak berlaku berdasarkan Peraturan Otoritas Jasa Keuangan Nomor 57/POJK.04/2020 tentang Penawaran Efek Melalui Layanan Urun Dana Berbasis Teknologi Informasi (POJK 57/POJK.04/2020).

Berdasarkan pada konsep kegiatan penanaman modal, maka ECF dapat digolongkan sebagai kegiatan penanaman modal tidak langsung. Sebagaimana dijelaskan pada paragraf sebelumnya bahwa dalam ECF setidaknya terdapat tiga pihak yakni penerbit, penyelenggara, dan pemodal. Pemodal/investor dalam kegiatan ECF tidak dibebankan secara langsung untuk berperan dalam kegiatan operasional dari ECF, namun hanya sebatas pihak yang meletakkan modalnya untuk dikelola. Sehingga dalam kegiatan ECF, investor tidak menanggung secara langsung resiko yang terjadi.

ECF di Indonesia memiliki rambu-rambu yang harus dipatuhi dalam pelaksanaannya. Berikut beberapa rambu-rambu yang menjadi sorotan penulis dalam penelitian hukum ini:

1.Kriteria pemodal

2.Jangka waktu penjualan kembali

3.Batasan jumlah pemegang saham

Lahirnya kegiatan ECF sendiri pada dasarnya adalah untuk menjadi wadah bagi para emiten kecil dan menengah untuk memperoleh pendanaan dalam bentuk urun dana dengan 
memanfaatkan teknologi informasi. Alternatif tersebut apabila melihat pada landasan dibentuknya POJK 57/POJK.04/2020 salah satu tujuannya adalah untuk memperluas cakupan penawaran efek dalam kegiatan urun dana, sehingga dapat dikatakan bahwa POJK 57/POJK.04/2020 bermaksud untuk memaksimalkan kegiatan ECF itu sendiri semaksimal mungkin. Meski demikian dalam POJK 57/POJK.04/2020 memiliki batasan-batasan yang harus diikuti oleh pelaku usaha, hal ini menarik bagi penulis karena tujuan utama perluasan cakupan penawaran efek harus diikuti dengan aturan hukum yang mendukungnya. Sehingga penulis bermaksud untuk mengkaji batasan-batasan yang ada dalam kegiatan ECF di Indonesia dan membandingkannya dengan kegiatan ECF yang ada di Amerika Serikat agar dapat ditemukan aturan hukum yang efektif dan sesuai dengan kebutuhan pelaku usaha UMKM/startup.

Amerika sebagai salah satu negara yang menjadi kiblat pasar modal, memiliki kebijakan yang memberi ruang bagi rakyatnya yang ingin menghimpun dana melalui skema menyerupai IPO, namun dengan prosedur lebih mudah. Pada 18 Desember 2013 menjadi titik awal startup dan usaha kecil untuk mendapatkan modal di dalam pasar modal, U. S. Securities and Exchange Commission (SEC) bermaksud untuk mengimplementasikan Title IV of the Jumpstart Our Business Startups Act of 2012 (the "JOBS Act"). Jobs act merupakan sebuah peraturan yang secara umum disebut Regulation A+ (Reg A+), yang ditetapkan dengan tujuan memperluas manfaat dari Regulation A. Reg A+ memberikan kesempatan pada perusahaan tertutup untuk mendapatkan modal hingga 5 juta USD. Hal ini memungkinkan publik untuk dapat melakukan permintaan saham yang diperdagangkan secara bebas di bursa layaknya kegiatan go public pada umumnya. Reg A+ dibuat dengan memberikan metode yang lebih murah dan mudah untuk perusahaan kecil agar dapat menghimpun modal. (Anthony, 2017)

Berdasarkan pengalaman Amerika dalam menerapkan Reg A+ untuk membantu UMKM dan startup untuk mendapatkan modal, kemudian menjadi topik yang menarik bagi penulis untuk melakukan penelitian ini. Sehingga penulis bermaksud untuk menyusun penelitian dengan rumusan masalah perkembangan regulasi ECF di Indonesia dan reformasi aturan hukum batasan investor dalam ECF di Indonesia.

\section{Metode Penelitian}

Tulisan ini merupakan penelitian hukum normative (normative legal research). Peter Mahmud Marzuki menyampaikan bahwa "Penelitian Hukum merupakan suatu proses untuk menemukan aturan hukum, prinsi-prinsip hukum, maupun doktrin-doktrin hukum guna menjawab isu hukum yang dihadapi". (Marzuki, 2010). Terdapat dua sumber bahan hukum dalam penelitian ini, yakni bahan hukum primer berupa perundang-undangan yang relevan dengan pembahasan penelitian. Bahan hukum sekunder terdiri dari buku, jurnal, dan kamus. Teknik pengumpulan bahan hukum menggunakan studi kepustakaan (library research), dilakukan dengan terlebih dahulu mengumpulkan bahan-bahan hukum, baik bahan hukum primer maupun sekunder, kemudian menginventarisnya melakukan inventarisasi dalam kategori primer atau sekunder dan kemudian menghubungkannya dengan permasalahanpermasalahan yang ada dalami penelitian ini. Metode analisis yang digunakan dalam penelitian ini menggunakanadalah penalaran yang bersifat deduktif, yakni penalaran untuk menarik kesimpulan dengan beranjak dari hal yang bersifat umum ke hal yang khusus. Menggunakan silogisme tradisional, yakni menghubungkan antara norma-norma hukum sebagai premis mayor dengan fakta-fakta yang relevan (legal facts) sebagai premis minor dan ditarik kesimpulan dari dua premis tersebut. Metode pendekatan yang digunakan adalah
Jurnal Yustika Vol. 24 No. 01, Juli 2021

Halaman | 40 Regulation A+ Sebagai Alternatif Penghimpun Dana Untuk UMKM DAN Start-Up

Dinda Silviana Putri 
Jurnal Yustika

Vol. 24 No. 01, Juli 2021

Halaman | 41

Regulation A+

Sebagai Alternatif

Penghimpun Dana Untuk UMKM DAN Start-Up

Dinda Silviana Putri pendekatan konsep (conceptual approach), pendekatan perundang-undangan (statute approach) dan pendekatan perbandingan (comparative approach).

\section{Pembahasan}

\subsection{Hambatan Perkembangan Regulasi Equity Crowd Funding di Indonesia}

Negara selalu berusaha memaksimalkan peranan UMKM sebagai usaha yang tetap mampu bertahan dalam krisis, baik di negara maju maupun berkembang dengan tujuan untuk menjaga stabilitas ekonomi negara yang bersangkutan. (Lestari \& Raja, 2020) Hal tersebut dilakukan karena UMKM merupakan salah satu media yang dapat menfasilitasi perkembangan perekonomian tidak hanya golongan menengah ke atas, namun juga menengah ke bawah. Kegiatan-kegiatan usaha dalam UMKM maupun start up seringkali merupakan kegiatan usaha dengan orientasi besar ke depan. Upaya pemerintah dalam mengakomodir kebutuhan UMKM dan start up tersebut salah satunya dengan menggunakan layanan urun dana (equity crowd funding/ECF). ECF dapat dikategorikan sebagai penanaman modal tidak langsung sebagaimana dijelaskan dalam pemaparan sebelumnya. Tujuan utama adanya kegiatan ECF di sini apabila melihat dari dasar filosofis yang ada di dalam konsideran POJK 57/POJK.04/2020 adalah menempatkan kegiatan urun dana sebagai salah satu alternatif pendanaan bagi UMKM maupun pelaku usaha pemula untuk mengumpulkan dana dengan penawaran efek melalui pasar modal.

Konsep penawaran efek yang ada di ECF dan kegiatan jual beli efek yang dilakukan perusahaan terbuka dalam pasar modal pada dasarnya merupakan konsep yang serupa. Sebagaimana ditegaskan dalam Pasal 1 angka 1 POJK 57/POJK.04/2020 bahwa:

"Penawaran Efek melalui Layanan Urun Dana Berbasis Teknologi Informasi yang selanjutnya disebut Layanan Urun Dana adalah penyelenggaraan layanan penawaran efek yang dilakukan oleh penerbit untuk menjual efek secara langsung kepada pemodal melalui jaringan sistem elektronik yang bersifat terbuka."

Sama halnya dengan kegiatan jual beli efek di pasar modal, dalam kegiatan ECF juga menyebutkan bahwa yang tergolong efek yang dapat diterbitkan adalah pengakuan utang, surat berharga komersial, saham, obligasi, tanda bukti utang, unit penyertaan kontrak investasi kolektif, kontrak berjangka atas Efek, dan setiap derivatif dari Efek. Meski demikian perbedaan mendasar antara efek di ECF dan efek yang ditawarkan oleh perusahaan terbuka pada umumnya terdapat pada segi kuantitas pemegang saham penerbit dan jumlah modal disetor. Berdasarkan Pasal 4 POJK 57/POJK.04/2020 ditegaskan apabila jumlah penerbit lebih dari 300 pihak dan jumlah modal disetor penerbit lebih dari Rp. 30.000.000.000,- maka penerbit digolongkan sebagai perusahaan publik sebagaimana diatur dalam Undang-Undang Nomor 8 Tahun 1995 tentang Pasar Modal. Hal demikian kiranya menjadi perhatian pemerintah dalam menyusun kebijakan ECF, karena pada dasarnya kegiatan ECF tersebut ditujukan pada UMKM dan start up sebagaimana dijelaskan sebelumnya. UMKM dan start up sebagai kegiatan usaha yang memiliki target pencapaian yang tinggi tentu saja tidak akan cukup hanya menggantungkan pada modal yang kecil, mengingat kegiatan usaha merupakan sebuah kegiatan yang sangat dinamis. Agar mampu menjadi unggul di bidangnya, maka pendiri harus selalu melakukan inovasi dan pengembangan atas kegiatan usahanya tersebut.

Dalam melakukan pengembangannya tersebut tentu memerlukan modal. Modal kerja dapat diperoleh dari proses perputaran aktiva maupun pasiva dari usaha yang bersangkutan. (Sugiono, 2015) Pelaku usaha yang bermaksud untuk menambah modalnya dapat dilakukan 
dengan mengajukan pinjaman ke bank maupun menjual saham dari perusahaannya. Dalam melakukan penjualan saham terdapat beberapa alternatif yakni (Rusdin, 2006) :

1. Dijual kepada pemegang saham sebelumnya.

2. Dijual kepada karyawan perusahaan bersangkutan (employee stock ownership plan).

3. Menambah saham melalui deviden yang tidak dibagi (dividend reinvestment plan).

4. Menjual secara private placement.

5. Dijual kepada publik (go public).

Skema pengumpulan dana seringkali sangat sulit dilakukan oleh pelaku usaha kecil, mengingat apabila hendak mengajukan pinjaman ke bank maka tentu saja bank harus memperhatikan kemampuan dari calon debitor. Lebih dari itu, perbankan juga dituntut untuk menerapkan prinsip analisis pembiayaan apabila hendak melakukan pembiayaan kepada nasabah. Secara umum prinsip analisis pembiayaan tersebut didasarkan pada 5C (The Five's Principles of Credit Analysis ). (Usanti \& Thalib, 2016) 5C tersebut merupakan prospek usaha dari calon nasabah yang terdiri dari character, capacity, capital, collateral dan condition. Hal tersebut merupakan konsekuensi dari prinsip kehati-hatian yang harus dilakukan perbankan. Prinsip kehatian-hatian sendiri ada karena alasan-alasan, yakni yang pertama perlindungan terhadap investor, nasabah penyimpan dana, peserta pasar uang, pemegang polis, penuntut kebijakan atau orang-orang yang terlibat sebagai fiduciary duty atas hutang. Kedua, menjaga keamanan, integritas atau tanggung jawab dari lembaga penyedia jasa keuangan. Ketiga, menjamin integritas dan stabilitas keuangan para pihak. (Panourgias, 2006)

Hal-hal tersebut di atas kemudian yang menjadikan UMKM maupun start up mengalami kesulitan dalam mengembangkan kegiatan usahanya. Berbeda dengan perusahaan besar, ketika memerlukan modal mereka dapat memperoleh modal dari perbankan karena jumlah aset yang dimilikinya terbilang besar dan dapat menjual sahamnya ke publik dengan cara IPO. Kelebihan-kelebihan itu tidak dimiliki oleh UMKM ataupun start up, sehingga mereka memerlukan usaha yang lebih untuk mengumpulkan modal dan mengembangkan kegiatan usahanya.

Pada tahun 2018, melalui POJK 37/POJK.04/2018 pemerintah Indonesia menunjukkan perhatiannya pada UMKM dan start up yang membutuhkan modal untuk membantu membiayai kegiatan usahanya. POJK 37/POJK.04/2018 kemudian dicabut dan dinyatakan tidak berlaku berdasarkan Peraturan Otoritas Jasa Keuangan Nomor 57/POJK.04/2020 tentang Penawaran Efek Melalui Layanan Urun Dana Berbasis Teknologi Informasi (POJK 57/POJK.04/2020) atau sering disebut sebagai crowd funding. Crowd funding dapat diartikan sebagai kegiatan urun dana atau penggalangan dana masyarakat umum dengan menggunakan jaringan internet yang bersifat masif, karena dalam crowd funding tersebut melibatkan banyak orang yang tidak saling mengenal dengan jangka waktu yang sangat cepat. (Iswi Hariyani, Cita Yustisia, 2019)

Kegiatan crowd funding dibagi menjadi empat kategori yakni, layanan urun dana berbasis donasi, layanan urun dana berbasis penghargaan, layanan urun dana berbasis pinjaman, dan layanan urun dana berbasis permodalan. (Nir Vulkan, Thomas Astebro, Manuel Fernandez Sierra, 2016) Fokus bentuk urun dana yang ada di dalam POJK 57/POJK.04/2020 merupakan kegiatan urun dana berupa pengumpulan equity atau modal. Dalam ECF di Indonesia berdasarkan POJK 57/POJK.04/2020 terdapat batasan dalam kegiatan penjualan efek yang menurut Penulis ditakutkan dapat menghambat pelaksanaan dari ECF, yaitu:

1. Kriteria pemodal 
Jurnal Yustika

Vol. 24 No. 01, Juli 2021

Halaman | 43

Regulation A+

Sebagai Alternatif

Penghimpun Dana Untuk UMKM DAN Start-Up

Dinda Silviana Putri
2. Jangka waktu penjualan kembali

3. Batasan jumlah pemegang saham

Pertama, kriteria pemodal yang dimaksudkan dalam Pasal 56 ayat (3) POJK 57/POJK.04/2020 dibagi menjadi dua yakni pemodal dengan penghasilan hingga Rp. 500.000.000.,- per tahun dapat membeli efek maksimal 5\% dari penghasilannya per tahun dan pemodal dengan penghasilan lebih dari Rp. 500.000.000.,- per tahun, dapat membeli efek maksimal 10\% dari penghasilannya per tahun. Adanya batasan atas pembelian efek tersebut pada satu sisi mencoba memberikan perlindungan bagi pemodal dalam mengalokasikan dananya, namun pada sisi yang lain apabila pemodal merupakan orang yang sudah memiliki pengalaman dalam investasi cenderung dapat menganggap hal tersebut memberikan hambatan bagi pemodal. Hal tersebut dikarenakan pemodal cenderung memiliki perhitungan yang matang tentang besar kecilnya modal yang akan dikeluarkan dengan kemungkinan keuntungan yang akan diperoleh nantinya.

Kedua, jangka waktu penjualan kembali. Berbeda dengan kegiatan jual beli saham di pasar modal yang dapat menjual kembali efek yang telah dibelinya di dalam pasar sekunder, dalam EFC di Indonesia terdapat aturan rentang waktu tertentu tentang penjualan efek yang telah dibeli pemodal kepada pemodal yang lainnya. Dalam Pasal 43 POJK 57/POJK.04/2020 diatur mengenai perdagangan efek penerbit yang telah dijual melalui layanan urun dana. Pasal 43 ayat (2) POJK 57/POJK.04/2020 kemudian memberikan ketentuan-ketentuan yang harus diikuti dalam memperdagangkan efek Penerbit, yaitu:

1. Hanya berlaku untuk saham yang telah didistribusikan minimal satu tahun sebelum perdagangan efek;

2. Dilakukan oleh sesama Pemodal yang terdaftar pada Penyelenggara;

3. Hanya dapat melakukan dua kali perdagangan efek dalam jangka waktu 12 bulan;

4. Jangka waktu perdagangan efek dengan perdagangan efek lainnya minimal enam bulan.

Kemudian di dalam Pasal 43 ayat (3) POJK 57/POJK.04/2020 menegaskan bahwa "Perdagangan Efek sebagaimana dimaksud pada ayat (2) huruf c dilarang dilaksanakan dalam jangka waktu lebih dari 10 (sepuluh) hari kerja." Adanya pembatasan-pembatasan penjualan efek tersebut dapat menjadi pertimbangan yang menghambat bagi pemodal ketika hendak menginvestasikan modalnya di dalam ECF, karena mereka tidak dapat mengambil atau menjual kembali efek yang mereka beli. Sedangkan bagi pengusaha, mereka perlu membaca situasi dalam menempatkan modal miliknya. Sehingga tidak jarang mereka akan lebih memilih berinvestasi di pasar sekunder yang ada di dalam bursa.

Ketiga, batasan pemegang saham. Dalam Pasal 4 POJK 57/POJK.04/2020 memberikan batasan bahwa penerbit dikatakan perusahaan publik sebagaimana diatur dalam UndangUndang Nomor 8 Tahun 1995 tentang Pasar Modal (UU Pasar Modal) apabila jumlah pemegang saham penerbit lebih dari 300 pihak. Ketentuan ini seolah telah mencederai dari semangat crowd funding itu sendiri, sebagaimana dituliskan di dalam konsideran POJK 37/POJK.04/2018 maupun POJK 57/POJK.04/2020 memiliki cita-cita bahwa ECF diharapkan dapat menjadi alternatif untuk UMKM dan start up untuk menghimpun dana dan sebagai sarana masyarakat luas untuk melakukan investasi. Dengan adanya pembatasan tersebut, ditakutkan dapat membatasi semangat gerak dari pengumpulan dana melalui kegiatan urun dana berbasis teknologi informasi.

3.2 Reformasi Aturan Hukum Batasan Investor dalam Equity Crowd Funding di Indonesia 3.2.1. Perkembangan Kebijakan Pengumpulan Dana Bagi Start up di Amerika Serikat 
Presiden Amerika Serikat Barack Obama pada April 2012 telah menandatangani the Jumpstart Our Business Startups Act (JOBS Act). (Newman, 2018) Title IV JOBS Act diberi nama Small Company Capital Formation, yang mengharuskan SEC untuk mengadopsi regulasi baru berdasarkan pada Regulation A. Setelah SEC melakukan amandemen, Reg A+ efektif sejak 19 Juni 2015. (Knyazeva, 2016) Reg A+ secara sederhana dapat diartikan sebagai proses hukum sebuah perusahaan dalam melakukan registrasi kepada SEC sehingga perusahaan tersebut dapat menjual surat utang maupun efek dengan tujuan untuk mendapatkan modal. (Anthony, 2017)

Masalah pengangguran menjadi pertimbangan utama diperkenalkannya beberapa bills pada tahun 2011 di Amerika yang menjadi upaya nyata untuk meningkatkan akses modal bagi pengusaha. (Thomas Lee Hazen, 2012) Beberapa aturan tersebut dimotivasi oleh keinginan untuk meningkatkan pertumbuhan ekonomi yang ternyata sangat dipengaruhi oleh munculnya perusahaan-perusahaan baru di Amerika. Meskipun ukurannya kecil, startup bertanggung jawab atas sebagian besar penciptaan lapangan kerja. Menurut sebuah laporan oleh Kauffman Foundation sebuah yayasan Nirlaba di Amerika yang memang bergerak dalam pendidikan kewirausahaan. (Kane, 2010) Perusahaan-perusahaan di Amerika paling tidak menambahkan kurang lebih tiga juta lapangan pekerjaan tiap tahunnya. Peningkatan lapangan kerja yang disediakan oleh perusahaan-perusahaan baru terlihat relatif lebih tangguh dibandingkan dengan sumber-sumber pekerjaan lain. Misalnya selama tahun-tahun resesi, penciptaan lapangan kerja di perusahaan rintisan tetap stabil, sementara index hilangnya pekerjaan di perusahaan yang sudah ada sangat sensitif terhadap siklus bisnis yang terjadi. (Kane, 2010)

Menariknya, penelitian menunjukkan bahwa 92\% pertumbuhan pekerjaan untuk perusahaan baru terjadi setelah penawaran umum perdana. (Association, 2011) The Kauffman Foundation memperkirakan bahwa jika perusahaan-perusahaan go public pada dekade pertama abad ke-21 dengan kecepatan yang sama dengan yang mereka lakukan antara 1980 dan 2000, tambahan 1.881 juta pekerjaan akan tercipta selama dekade itu. (Association, 2011) Mengingat angka-angka yang mengejutkan itu, mudah untuk memahami mengapa Kongres dan SEC telah menjadikannya prioritas untuk menciptakan jalan yang lebih mulus bagi perusahaanperusahaan yang sedang tumbuh, dengan mencoba memberikan penawaran kepada perusahaan pemula (mini-IPO) yang lebih murah dan lebih mudah berdasarkan Reg A. Reg A menawarkan banyak manfaat sebagai berikut: (Guzik, 2014)

1. pengurangan keterbukaan kepada investor;

2. kemampuan untuk (water testing) sebelum menimbulkan biaya di awal yang signifikan seperti mengajukan nota penawaran dengan SEC;

3. kemampuan seorang investor untuk menerima saham perdagangan bebas setelah penerbitannya, dan

4. tidak adanya persyaratan pelaporan pasca-penawaran kecuali dan sampai perusahaan memenuhi persyaratan pelaporan ambang batas yang berlaku untuk semua perusahaan di bawah Securities Exchange Act of 1934."

Di lain sisi, Reg A ternyata terbukti tidak populer, hal ini terlihat dari tahun 1997 hingga 2011, jumlah pengajuan per tahun dimulai hanya 116 dan turun menjadi 19. Pada tahun 2011, hanya ada satu dari 19 pengajuan yang menghasilkan penawaran dan memenuhi syarat Reg A. Akibatnya, pengajuan Reg A kalah dari kedua penawaran Regulation D (8194 pada 2011) dan IPO terdaftar (312 pada 2011). (Office, 2012) 
Jurnal Yustika

Vol. 24 No. 01, Juli 2021

Halaman | 45

Regulation A+

Sebagai Alternatif

Penghimpun Dana Untuk UMKM DAN Start-Up

Dinda Silviana Putri
Pemanfaatan yang rendah ini umumnya dikaitkan dengan tingginya biaya melakukan penawaran yang ada di dalam Reg A, apabila dibandingkan dengan jumlah yang dapat dinaikkan. Sebagian besar biaya timbul dari kebutuhan untuk mematuhi Blue Sky Laws (kebijakan negara yang mewajibkan perusahaan yang menawarkan atau menjual efek harus terdaftar di negara bagian. (Jr, 2017)) Setiap negara bagian di mana penawaran dilakukan, setidaknya memerlukan waktu dan uang yang tidak sedikit. Aturan dalam Blue Sky Law yang paling memberatkan adalah mengenai tinjauan kelayakan. Selain itu, Reg A memberi batasan modal yang dapat dikumpulkan hanya sebesar 5 juta dollar dianggap terlalu rendah untuk dapat memberikan dampak yang efektif pada perusahaan-perusahaan baru setelah sebelumnya telah menanggung beban biaya yang tidak sedikit.

Menyadari kegagalan pemberlakuan dari Reg A, yang mulanya merupakan upaya dukungan pada emiten kecil, kemudian Kongres memilih untuk memperbaharui regulasi dalam Title IV dari JOBS act. Bentuk Reg A yang disempurnakan ini disebut sebagai Reg A+. Dengan kata lain, Reg A+ merupakan nama yang diberikan pada aturan yang diadopsi oleh SEC. dalam amandemen tersebut, Reg A+ juga memperluas apa yang ditawarkan oleh Reg A sebelumnya. Penawaran tersebut dibagi menjadi dua tingkat, yaitu (Knight \& Lay):

1. Tingkat 1 , yang terdiri dari penawaran efek hingga 20 juta USD dalam periode 12 bulan. Pada tingkat 1 ini tidak dibatasi siapa dan berapa investasi boleh dilakukan, namun membutuhkan persetujuan SEC dan negara bagian di bawah ketentuan blue sky law.

2. Tingkat 2, yang terdiri dari penawaran efek hingga 50 juta USD dalam periode 12 bulan. Pada tingkat dua terdapat batasan, dimana investor yang tidak terakreditasi tidak boleh melakukan inventasi lebih dari $10 \%$ dari pendapatan atau dari kekayaannya, entities sebanyak $10 \%$ dari revenue atau aset bersih, sedangkan investor yang terakreditasi tidak memiliki batasan. Namun tidak seperti pada tingkat 1 , dalam tingkatan ini hanya memerlukan persetujuan dari SEC, sehingga terhindarkan dari ketentuan yang ada dalam blue sky laws.

Pada Reg A+ terjadi dua perubahan mendasar, pertama ialah terjadinya peningkatan penawaran efek yang semula dibatasi hanya sebesar 5 juta USD. Kedua adalah pada tingkat dua, tidak dibutuhkan blue sky law requirments dalam mengumpulkan modal, sehingga lebih cepat dan lebih murah.

Media pengumpulan modal bagi start up di Amerika tidak hanya melalui Reg A+, namun sama halnya dengan Indonesia, Amerika juga memiliki kebijakan tentang ECF. Dalam Title III Jobs Act diatur mengenai crowd funding. Baik Reg A+ dalam Title IV Jobs Act maupun crowd funding dalam Title III Jobs Act, keduanya mengatur mengenai cara menghimpun dana untuk para pelaku usaha start up, namun yang membedakan adalah dari segi:

1. Batasan bagi investor

2. Jumlah modal yang dapat diperoleh oleh perusahaan

3. Perbedaan keterbukaan

4. Persyaratan yang diperlukan

\subsubsection{Perbandingan Kebijakan ECF di Amerika dan Regulation A+}

Amerika Serikat juga memiliki aturan yang mengatur tentang ECF, yakni di dalam Title III Jobs Act, seringkali disebut sebagai Crowd funding Act. Peraturan tersebut sebenarnya tidak berbeda dengan aturan ECF yang ada di Indonesia, seperti misalnya seorang investor yang 
terlibat dengan ECF boleh menginvestasikan tidak lebih dari 5\% dari pendapatnya jika pendapatan pertahunnya kurang dari 100.000 dollar, sedangkan yang lebih tinggi dari itu, boleh menginvestasikan sebesar 10\%. (Cunningham, 2012) Selain itu, juga ada kewajiban bagi penyelenggara untuk memberikan berbagai informasi yang diperlukan misalnya seperti resiko dan kewajiban untuk memberikan solusi jika ada permasalahan yang dihadapi oleh investor. Penyelenggara juga memiliki kewajiban agar perusahaan-perusahaan berkembang yang akan didanai, agar tidak didanai terlebih dahulu sebelum mereka mencapai target penghasilan sejak dikumpulkannya modal awal. Dengan kata lain, suatu perusahaan yang berkembang tersebut tidak serta merta langsung didanai, namun setidaknya sudah menghasilkan pendapatan sebesar 1 juta dollar. (Cunningham, 2012)

Peraturan mengenai ECF di Amerika juga mewajibkan penerbit untuk memberikan informasi pada investor berkaitan dengan data-data mengenai struktural atau susunan pemilik perusahaan, nama dan legalitas perusahaan (partner perusahaan jika ada), selain itu penerbit juga harus memberikan informasi terperinci mengenai lokasi fisik perusahaannya kepada investor. Selain itu penerbit juga harus memberikan informasi kepada investor yang memiliki $20 \%$ atau lebih saham yang diikutkan ke program ECF, mengenai projek perusahaan yang sangat dinanti dan juga harus dimasukkan ke dalam rencana bisnis. (Cunningham, 2012) Tidak luput juga kondisi keuangan perusahaan juga harus disampaikan juga perpajakan atau audit.

Permasalahannya, sekalipun di atas kertas aturan ECF tersebut cukup detail dan menjanjikan, namun peminat dari program ini juga tidak banyak. Hal itu dikarenakan usaha yang harus dilakukan oleh penerbit cukup banyak hanya untuk mendapatkan uang dalam waktu yang singkat dan jumlah yang relatif tidak banyak. (Cunningham, 2012)

Berkaca pada penjabaran tersebut, sebenarnya peraturan tentang ECF maupun mini IPO dalam Reg A+ merupakan cara bagi pelaku usaha untuk menghimpun dana. Di Indonesia saat ini hanya dikenal ECF dan IPO, dan belum ada skema mini IPO. IPO atau lebih dikenal dengan penawaran umum/go public berdasarkan pada Pasal 1 angka 15 Undang-Undang Nomor 8 Tahun 1995 tentang Pasar Modal (UU Pasar Modal) merupakan "Kegiatan penawaran efek yang dilakukan oleh emiten untuk menjual efek kepada masyarakat berdasarkan tata cara yang diatur dalam undang-undang ini dan pelaksanaannya."

Mini IPO yang ditawarkan oleh Reg A+ merupakan bentuk lebih sederhana dari IPO itu sendiri. Alasan yang melatarbelakangi lahirnya mini IPO adalah kebutuhan dana yang lebih murah dalam pelaksanaannya, dimana hal tersebut merupakan kekurangan dari IPO. IPO kurang dapat memberikan bantuan kepada UMKM maupun startup karena sebagai bentuk usaha rintisan mereka cenderung memiliki dana yang sangat terbatas, sehingga bentuk pengumpulan dana yang memungkinkan adalah dengan ECF.

Metode pengumpulan dana melalui ECF dalam perjalanannya (sama halnya dengan Indonesia) memiliki hambatan-hambatannya, yaitu:

1. Membagi investor menjadi accredited investor dan non accredited investor (bergantung pada penghasilan yang dimiliki).

2. Total dana yang bisa dihimpun melalui ECF terbatas pada maksimal 5 juta dollar.

3. Usaha yang harus ditempuh oleh penerbit juga terlalu banyak. 
Jurnal Yustika

Vol. 24 No. 01, Juli 2021

Halaman | 47

Regulation A+

Sebagai Alternatif

Penghimpun Dana Untuk UMKM DAN Start-Up

Dinda Silviana Putri

Berbeda dengan ECF, perbedaan-perbedaan mini IPO dalam Reg A+ dengan ECF yakni sebagai berikut: Pertama, dalam mini IPO tidak membagi investor menjadi kategori-kategori tertentu, namun memberikan peluang bagi masyarakat luas (penduduk Amerika Serikat) untuk turut berpartisipasi menjadi investor. Kedua, dalam mini IPO, pelaku usaha start up dapat menghimpun dana yang dibagi dalam dua tingkatan. Tingkat pertama, sebesar maksimal 20 Juta dollar, sedangkan tingkat dua sebesar 75 juta dollar. Jumlah tersebut jauh lebih besar dibandingkan dengan ECF yang terbatas sejumlah lima juta USD. Ketiga, tindakan transaksi dalam ECF memiliki batasan waktu tertentu. Sedangkan dalam mini IPO, layaknya IPO pada umumnya maka pemegang efek diberi kewenangan dalam melakukan transaksi atas efek yang dimilikinya tanpa ada batasan waktu tertentu.

Perbandingan antara ECF dan REG A+ tersebut menunjukkan bahwa kelebihankelebihan yang ditawarkan dalam Reg A+ (mini IPO) sebagaimana dijelaskan di atas, kiranya dapat menjadi solusi untuk memaksimalkan pelaksanaan ECF yang ada di Indonesia. Hal ini dikarenakan antara konsep ECF di Indonesia dan di Amerika sendiri pada hakikatnya sama. Oleh karenanya, perbaikan regulasi melalui di-adopsinya beberapa ketentuan yang ada pada Reg A+ diharapkan dapat memberikan manfaat pada UMKM maupun start up dengan memaksimalkan sarana ECF untuk menghimpun dana, selain itu, dapat menjadi cara agar masyarakat juga dapat turut berperan aktif dalam kegiatan investasi.

\section{Kesimpulan}

Berdasarkan pemaparan sebagaimana dijelaskan penulis di atas, maka dapat diketahui bahwa salah satu faktor utama yang menghambat UMKM dan startup adalah modal usaha. Modal usaha dapat diperoleh dari modal internal, perbankan dan kegiatan IPO. Namun bagi kalangan UMKM dan startup, kegiatan IPO justru memberatkan karena memerlukan biaya dan skema administrasi yang rumit. Dalam hal ini penulis menemukan bahwa di Amerika Serikat berhasil menangani masalah tersebut dengan menghadirkan Reg A+ (Mini IPO) sebagai solusi yang lebih efisien dan mudah dibandingkan dengan ECF sebagaimana diatur dalam POJK 57/POJK.04/2020. Perbaikan-perbaikan dalam ECF di Indonesia sangat diperlukan demi mendukung berkembangnya UMKM dan start up, utamanya dari segi kriteria pemodal, ketentuan dalam penjualan efek kembali, dan jumlah pemilik efek.

\section{Daftar Referensi}

Anthony, L. (2017, Januari). Regulation A+ IPO or The Mini-IPO; Remarkably Effective and Widely Misunderstood. Whitepaper, p. 2.

Association, N. V. (2011). Venture Impact: Economic Importance of Venture Capital-Backed Companies to the US Economy 3 (6 ed.).

Cunningham, W. M. (2012). The Jobs Act: Crowdfunding for Small Businesses and Startups. New York: Apress.

Dr. Mas Rahmah, S. M. (2019). Hukum Pasar Modal. Jakarta: Kencana.

Guzik, S. (2014). Regulation A+ Offerings-A New Era at the SEC. 
Higgins, K. (2014). The Changing Regulatory Landscape for Angel Investing. Harvard Law School Forum on Corporate Government.

Jurnal Yustika Vol. 24 No. 01 , Juli 202

Iswi Hariyani, Cita Yustisia. (2019). Kajian Hukum Bisnis Jasa Crowdfunding Properti. Legislasi Indonesia, 16(1), 45.

Jr, R. B. (2017). The Case for Federal Pre-Emption of State Blue Sky Laws. In R. B. Jr, Prosperity Unleashed: Smarter Financial Regulation (p. 84). Washington: The Heritage Foundation.

Kane, T. (2010). The Importance of Startups in Job Creation and Job Destruction. Kansas City: Ewing Marion Kauffman Foundation.

Knight, J. H., \& Lay, W. N. (n.d.). Faqs About Regulation A+ Securities Offerings. Washington DC.

Knyazeva, A. (2016). Regulation A+: What Do We Know So Far? 1.

Lestari, E., \& Raja, W. R. (2020). Analisis Modal Kerja Pada UMKM (Usaha Mikro Kecil dan Menengah) dalam Meningkatkan Laba Usaha. Optima, 3, 24. doi:10.33366/optima.v3i2.1755

Lukito, I. (2017, November). Tantangan Hukum dan Peran Pemerintah Dalam Pembangunan ECommerce. JIKH, 11, 351.

Marzuki, P. M. (2010). Penelitian Hukum (sixth ed.). Jakarta, Indonesia: Rencana Prenada Media Group.

Newman, N. (2018). Regulation A+: New and Improved After the JOBS Act or Failed Revival. Virginia Law \& Business Review, 12, 245.

Nigel Savage, R. B. (1993). Business Law. London: Butterworth.

Nir Vulkan, Thomas Astebro, Manuel Fernandez Sierra. (2016). Equity Crowdfunding: A New Phenomena. Journal of Business Venturing Insights, 37.

Office, U. G. (2012). Securities Regulation: Factors That May Affect Trends in Regulation A Offerings.

Panourgias, L. E. (2006). Banking Regulation and World Trade Law: GATS, EU and 'Prudential' Intitution Building. Portland: Hart .

Rusdin. (2006). Pasar Modal: Teori, Masalah, dan Kebijakan Dalam Praktik. Bandung: Alfabeta.

Suci, Y. R. (2017, Januari). Perkembangan UMKM (Usaha Mikro Kecil dan Menengah) di Indonesia. Cano Ekonomos, 6, 57.

Sugiono. (2015). Analisis Penyediaan dan Penggunaan Modal Kerja UMKM (Usaha Mikro, Kecil dan Menengah) dalam Meningkatkan Laba Usaha pada KUB (Kelompok Usaha Besama) Alam Lestari Depok. Prosiding Semiar Nasional Pendidikan Ekonomi E Bisnis Fakultas keguruan dan ilmu Pendidikan Universitas Sebelas Maret Surakarta. 5.

Usanti, T. P., \& Thalib, P. (2016, May). Asas Ikhtiyati Pada Akda Pembiayaan Mudharabah Di Lingkungan Perbankan Syariah. Yuridika, 31, 311. doi:10.20473/ydk.v31i2.5190

Warren, D. M. (2011). Venture Capital Investment: Status and Trends.
Halaman | 48 Regulation A+ Sebagai Alternatif Penghimpun Dana Untuk UMKM DAN Start-Up

Dinda Silviana Putri 